\title{
EFFECT OF OXYTOCIN INFUSION ON REDUCING BLOOD LOSS DURING ABDOMINAL MYOMECTOMY
}

\author{
By
Abd El-Azeem Mohamed Ahmed, Ahmed Osama Abd El-Motaal and Osama Mahmoud Abd El-Rhim

Obstetrics and Gynecology Department, Faculty of Medicine, Al-Azhar University

Corresponding author: Osama Mahmoud Abd El-Rhim, Mobile: 01000161686

E-mail: osama_mahmoud4@hotmail.com

\begin{abstract}
Background: Open myomectomy remains the main option has been shown to have satisfactory results as regard fertility preservation and symptom resolution, especially when the number and size of leiomyomas do not permit any other routes of intervention. Hemorrhage remains the most important concern with open myomectomy. Blood loss during surgery mainly depends on the number, size of the removed fibroids and the technique adopted during myomectomy.
\end{abstract}

Objective: Evaluation of the effect of intra-operative oxytocin infusion in decreasing blood loss during abdominal myomectomy.

Patients and Methods: This controlled clinical trial was on 134 women: 67 interventional group and 67 control group who were candidates for elective abdominal myomectomy at Al-Hussein University Hospital. After induction of general anesthesia and immediately prior to the operation, an infusion of 30 IU oxytocin in $500 \mathrm{ml}$ normal saline at a rate of $120 \mathrm{ml} / \mathrm{h}$ was started in the study group patients during myomectomy. In placebo group patients, a pure normal saline infusion was used at the same volume and rate.

Results: There was no significant difference between the studied groups regarding preoperative hemoglobin. Postoperative hemoglobin was significantly higher among oxytocin group. Hemoglobin reduction was significantly lower among oxytocin group.

Conclusion: The infusion of oxytocin intra-operatively (immediately after induction of general anesthesia) may be a safe and reliable method to help decrease blood loss during abdominal myomectomy.

Keywords: Oxytocin; Abdominal Myomectomy.

\section{INTRODUCTION}

Uterine leiomyoma (fibroids) are the most common benign tumors among women (Kongnyuy and Wiysonge, 2011). Fibroids are found in approximately $20 \%$ of women over 35 years of age (Thomas et al., 2010). In 20-50\% of patients, fibroids may cause problems such as heavy menstrual bleeding, anemia, pelvic pain and pressure, and symptoms from extrinsic compression of the colorectal and urinary tract (Mohamed et al., 2019). Surgery is indicated for symptomatic uterine leiomyoma; hysterectomy for women who have completed childbearing (women > 40 years old), and myomectomy for women $<40$ years old who wish to preserve uterine and fertility (Ikhena and Bulun, 2018). 
Myomectomy can be accomplished by laparotomy, laparoscopy, or hysteroscopy (transvaginal) approaches (van der Does et al., 2018). This surgical procedure may be associated with substantial morbidity, in particular major blood loss (Schüring et al., 2011), especially in abdominal myomectomy. Blood transfusion can be required in up to $20 \%$ of the women during abdominal myomectomy (Misırlıoğlu et al., 2018). A number of interventions have been introduced to reduce bleeding rate during myomectomy, such as use of tourniquets, uterine artery dissection, vaginal misoprostol, intramyometrial infiltration of bupivacaine plus epinephrine, injection of vasopressin into the uterus, preoperative administration of gonadotropin-releasing hormone (GnRH) agonist, and preoperative injection of ascorbic acid. However, these strategies may be associated with some complications, and some of these are ineffective or expensive or required extra steps before the actual procedure (Helal et al., 2010).

Oxytocin is a hormone secreted mainly from the pituitary gland. Its main function is uterine contraction during labour and delivery. Oxytocin is the agent of choice in the prevention of postpartum uterine atony and bleeding (Atashkhoei et al., 2017), but should be used cautiously because an intravenous bolus of $10 \mathrm{IU}$ oxytocin could be detrimental to women with heart disease or to women who are hypovolemic (Tektook et al., 2019). Oxytocin receptors exist in the nonpregnant uterus, although the concentration of the receptors is much lower than in its pregnancy. It is for this reason that the clinical use of oxytocin outside of pregnancy is limited (Shokeir et al., 2011).

Myomectomy is an operation where significant hemorrhage can occur. In light of the effectiveness of oxytocin on the postpartum uterus, there is interest in the use of oxytocin to reduce uterine perfusion and therefore bleeding during myomectomy. Shokier et al. (2011) reported that oxytocin infusion reduces the observed reduction in hematocrit after hysteroscopy myomectomy. Atashkhoei et al. (2017) discovered the ability of oxytocin to reduce the hemorrhage and subsequent blood transfusion requirement during laparoscopic myomectomy and laparoscopic vaginal hysterectomy. The one published randomized double-blind study did not show any benefit of using oxytocin in preventing bleeding during abdominal and vaginal myomectomy (Çetin et al., 2019). In view of the lack of data, we designed a trial to evaluate the efficacy of pre-operative administration of oxytocin on reducing bleeding during abdominal myomectomy.

The aim of this study was to evaluate the effect of intra-operative oxytocin infusion in decreasing blood loss during abdominal myomectomy.

\section{PATIENTS AND METHODS}

This was a prospective study with randomization into two parallel groups with intervention and placebo allocation ratio of $1: 1$. The study was carried at AlHussein University Hospital from February 2019 to November 2019. Subjects who were candidates for elective abdominal myomectomy (134 patients) were enrolled in this study, 67 
interventional groups and 67 control group.

Patients were recruited in the study according to the following inclusion criteria: Age 20- 45 years, intramural fibroids diagnosed by ultrasound imaging and preoperative $\mathrm{Hb}$ concentration $>10$ $\mathrm{mg} / \mathrm{dl}$.

Patients with cardiovascular or respiratory disease, those were planned for hysteroscopy or laparoscopic myomectomy, patients with sub mucosal fibroids and patients with preoperative $\mathrm{GnRH}$ agonist consumption were excluded from the study.

Patients were investigated by full history, general and specific examination and laboratory tests (CBC, HCT, fasting and postprandial blood glucose, kidney and liver function tests, coagulation profile) abdominal and transvaginal ultrasound.

After induction of general anesthesia and immediately prior to the operation, an infusion of $30 \mathrm{IU}$ oxytocin in $500 \mathrm{ml}$ normal saline at a rate of $120 \mathrm{ml} / \mathrm{h}$ was started in the study group patients during myomectomy. In control group patients, a pure normal saline infusion was used at the same volume and rate. In all operations, the abdomen was exposed through a Pfannensteil incision.

\section{Statistical methods:}

The collected data were coded, tabulated, and statistically analyzed using IBM SPSS statistics (Statistical Package for Social Sciences) software version 18.0, IBM Corp., Chicago, USA, 2009. Inferential analyses were done for quantitative variables using Shapiro-Wilk test for normality testing, independent ttest in cases of two independent groups with normally distributed data and Mann Whitney $U$ in cases of two independent groups with non-normally distributed data. In qualitative data, inferential analyses for independent variables were done using Chi square test for differences between proportions and Fisher's Exact test for variables with small expected numbers. The level of significance taken at $\mathrm{P}$ value $<0.050$ was significant. Intervention values were calculated as follows: Rate elevation=Study Rate Control Rate. Efficacy= (Study Rate Control Rate) / Study rate. Relative Rate= Study Rate / Control Rate. Number needed to treat $=1$ / (Study Rate - Control Rate).

\section{RESULTS}

The mean age of patients in oxytocin group was $32.3 \pm 3.5$ with the range 22.0 39.0 while in control group was $32.4 \pm 3.7$ with the range 24.0-40.0, the mean BMI of patients in oxytocin group was $24.9 \pm 2.3$ with the range $21.4-29.6$ while in control group was $25.1 \pm 2.3$ with the range $20.8-29.8$, the median of parity of patients in oxytocin group was 2 with the range 0 5 while in control group was 2 with the range 0-5 thus showing no significant differences between the studied groups regarding age, BMI and parity (Table 1).

The median number of myomas in patients in oxytocin group was 2 with the range 1-5 while in control group was 2 
with the range $1-5$, the mean maximum diameter of myoma in patients in oxytocin group was $3.8 \pm 0.6$ with the range $2.8-5.9$ $\mathrm{cm}$ while in control group was $4.0 \pm 0.7$ with the range $2.9-6.0 \mathrm{~cm}$, the mean uterine size in patients in oxytocin group was $18.5 \pm 1.7$ with the range $15-22$ weeks while in control group was $18.3 \pm 1.9$ with the range 14-23 weeks thus showing no significant differences between the studied groups regarding myoma number\& size and uterine size (Table 1).

Table (1): Demographic characteristics among the studied groups

\begin{tabular}{|c|c|c|c|c|}
\hline \multicolumn{2}{|l|}{ Parameters } & $\begin{array}{c}\text { Control } \\
(\mathrm{N}=67)\end{array}$ & $\begin{array}{c}\text { Oxytocin } \\
(\mathrm{N}=67)\end{array}$ & $\mathbf{P}$ \\
\hline \multirow{2}{*}{$\begin{array}{c}\text { Age } \\
\text { (years) }\end{array}$} & Mean \pm SD & $32.4 \pm 3.7$ & $32.3 \pm 3.5$ & \multirow{2}{*}{$\begin{array}{c}>> \\
0.05\end{array}$} \\
\hline & Range & $24.0-40.0$ & $22.0-39.0$ & \\
\hline \multirow{2}{*}{$\begin{array}{c}\text { BMI } \\
\left(\mathrm{kg} / \mathrm{m}^{2}\right)\end{array}$} & Mean \pm SD & $25.1 \pm 2.3$ & $24.9 \pm 2.3$ & \multirow{2}{*}{$\begin{array}{c}> \\
0.05\end{array}$} \\
\hline & Range & $20.8-29.8$ & $21.4-29.6$ & \\
\hline \multirow{2}{*}{ Parity } & Median (IQR) & $2.0(1.0-3.0)$ & $2.0(0.0-3.0)$ & \multirow{2}{*}{$\begin{array}{c}> \\
0.05\end{array}$} \\
\hline & Range & $0.0-5.0$ & $0.0-5.0$ & \\
\hline \multirow{2}{*}{$\begin{array}{l}\text { Myoma } \\
\text { number }\end{array}$} & Median (IQR) & $2.0(1.0-3.0)$ & $2.0(1.0-3.0)$ & \multirow{2}{*}{$\begin{array}{c}> \\
0.05\end{array}$} \\
\hline & Range & $1.0-5.0$ & $1.0-5.0$ & \\
\hline \multirow{2}{*}{$\begin{array}{l}\text { Maximum } \\
\text { diameter } \\
(\mathrm{cm})\end{array}$} & Mean \pm SD & $4.0 \pm 0.7$ & $3.8 \pm 0.6$ & \multirow{2}{*}{$\begin{array}{c}>> \\
0.05\end{array}$} \\
\hline & Range & $2.9-6.0$ & $2.8-5.9$ & \\
\hline \multirow{2}{*}{$\begin{array}{c}\text { Uterine size } \\
\text { (week) }\end{array}$} & Mean \pm SD & $18.3 \pm 1.9$ & $18.5 \pm 1.7$ & \multirow{2}{*}{$\begin{array}{c}> \\
0.05\end{array}$} \\
\hline & Range & $14.0-23.0$ & $15.0-22.0$ & \\
\hline
\end{tabular}

IQR: Inter-quartile range. ^Independent t-test, §Mann Whitney test

The mean intraoperative blood loss in oxytocin group was $392.8 \pm 68.2$ with the range $238.8-563.0 \mathrm{ml}$ while in control group was $547.8 \pm 77.8$ with the range $383.2-769.0 \mathrm{ml}$ showing that Intra- operative blood loss was significantly fewer among oxytocin group $(\mathrm{p}<0.001)$. The mean blood loss decrease due to oxytocin was $155.0 \pm 12.6$ (Table 2 ).

Table (1): Inraoperative blood loss ( $\mathrm{mL}$ ) among the studied groups

\begin{tabular}{|c|c|c|c|}
\hline $\begin{array}{l}\text { Groups } \\
\text { Parameters }\end{array}$ & $\begin{array}{c}\text { Control } \\
(\mathrm{N}=67)\end{array}$ & $\begin{array}{c}\text { Oxytocin } \\
(\mathrm{N}=67)\end{array}$ & ${ }^{\wedge} \mathbf{P}$ \\
\hline Mean \pm SD & $547.8 \pm 77.8$ & $392.8 \pm 68.2$ & \multirow{2}{*}{$<0.001$} \\
\hline Range & $383.2-769.0$ & $238.8-563.0$ & \\
\hline \multicolumn{4}{|c|}{ Value of oxytocin } \\
\hline Items & \multicolumn{2}{|c|}{ Mean \pm SE } & $95 \% \mathrm{CI}$ \\
\hline Blood loss decrease & \multicolumn{2}{|c|}{$155.0 \pm 12.6$} & $130.0-180.0$ \\
\hline
\end{tabular}

Independent t-test, CI: Confidence interval

The mean preoperative $\mathrm{Hb} \%$ in oxytocin group was $11.8 \pm 0.9$ with the range 10.1-13.7 while in control group was $11.7 \pm 1.0$ with the range 10.2-13.8 showing that there was no significant difference between the studied groups regarding preoperative hemoglobin. The mean postoperative $\mathrm{Hb} \%$ in oxytocin group was $10.9 \pm 0.8$ with the range 9.2-12.7 while in control group was $10.4 \pm 1.0$ with the range 8.7-12.7 showing that postoperative hemoglobin was significantly higher among oxytocin group ( $\mathrm{p}$ value 0.004 ). The mean $\mathrm{Hb} \%$ reduction in oxytocin group was $0.9 \pm 0.2$ with the range 0.5-1.4 while in control group was $1.2 \pm 0.3$ with the range $0.7-2.0$ showing that hemoglobin reduction was significantly lower among oxytocin group $(\mathrm{P}<0.001)$. The 
mean $\mathrm{Hb}$ reduction decrease due to oxytocin was $0.3 \pm 0.1$ (Table 3 ).

The mean preoperative Hematocrit \% in oxytocin group was $33.7 \pm 3.2$ with the range 27.9-41.1 while in control group was $33.5 \pm 3.8$ with the range $26.8-42.8$ showing that there was no significant difference between the studied groups regarding preoperative hematocrit. The mean postoperative hematocrit $\%$ in oxytocin group was $31.1 \pm 3.1$ with the range 25.5-38.8 while in control group was $29.9 \pm 3.7$ with the range 23.1-39.3 showing that postoperative hematocrit was significantly higher among oxytocin group ( $\mathrm{p}$ value 0.049 ). The mean hematocrit \% reduction in oxytocin group was $2.6 \pm 0.5$ with the range 1.4-3.7 while in control group was 3.5 \pm 0.7 with the range 2.1-5.4 showing that hematocrit reduction was significantly lower among oxytocin group $(\mathrm{P}<0.001)$. The mean hematocrit reduction decrease due to oxytocin was $0.3 \pm 0.1$ (Table 3).

Table (2): Hemoglobin (mg/dL) and Hematocrit (\%) among the studied groups

\begin{tabular}{|c|c|c|c|c|}
\hline \multicolumn{2}{|c|}{$\begin{array}{ll}\text { Parameters } & \text { Groups } \\
\end{array}$} & $\begin{array}{c}\text { Control } \\
(\mathrm{N}=67)\end{array}$ & $\begin{array}{c}\text { Oxytocin } \\
(N=67)\end{array}$ & ${ }^{\wedge} \mathbf{P}$ \\
\hline \multirow{2}{*}{ Before } & Mean \pm SD & $11.7 \pm 1.0$ & $11.8 \pm 0.9$ & \multirow{2}{*}{$>0.05$} \\
\hline & Range & $10.2-13.8$ & $10.1-13.7$ & \\
\hline \multirow{2}{*}{ After } & Mean \pm SD & $10.4 \pm 1.0$ & $10.9 \pm 0.8$ & \multirow{2}{*}{0.004} \\
\hline & Range & $8.7-12.7$ & $9.2-12.7$ & \\
\hline \multirow{2}{*}{ Reduction } & Mean \pm SD & $1.2 \pm 0.3$ & $0.9 \pm 0.2$ & \multirow{2}{*}{$<0.001$} \\
\hline & Range & $0.7-2.0$ & $0.5-1.4$ & \\
\hline \multicolumn{5}{|c|}{ Value of oxytocin } \\
\hline \multicolumn{2}{|c|}{ Item } & \multicolumn{2}{|c|}{ Mean \pm SE } & $95 \% \mathrm{CI}$ \\
\hline \multicolumn{2}{|c|}{ Reduction decrease } & \multicolumn{2}{|c|}{$0.3 \pm 0.1$} & $0.3-0.4$ \\
\hline \multirow{2}{*}{ Before } & Mean \pm SD & $33.5 \pm 3.8$ & $33.7 \pm 3.2$ & \multirow{2}{*}{$>0.05$} \\
\hline & Range & $26.8-42.8$ & $27.9-41.1$ & \\
\hline \multirow{2}{*}{ After } & Mean \pm SD & $29.9 \pm 3.7$ & $31.1 \pm 3.1$ & \multirow{2}{*}{$<0.044$} \\
\hline & Range & $23.1-39.3$ & $25.5-38.8$ & \\
\hline \multirow{2}{*}{ Reduction } & Mean \pm SD & $3.5 \pm 0.7$ & $2.6 \pm 0.5$ & \multirow{2}{*}{$<0.001$} \\
\hline & Range & $2.1-5.4$ & $1.4-3.7$ & \\
\hline
\end{tabular}

Blood transfusion was required in 6 patients $(9 \%)$ of oxytocin group while was required in 15 patients $(22.4 \%)$ of control group showing that Blood transfusion was significantly less frequent among oxytocin group(Table 4).

Table (3): Blood transfusion among the studied groups

\begin{tabular}{|l|c|c|c|}
\hline Parameters Groups & $\begin{array}{c}\text { Control } \\
(\mathbf{N = 6 7 )}\end{array}$ & $\begin{array}{c}\text { Oxytocin } \\
(\mathbf{N}=67)\end{array}$ & \multirow{2}{*}{$\wedge$} \\
\hline Required & $15(22.4 \%)$ & $6(9.0 \%)$ & \multirow{2}{*}{$\mathbf{0 . 0 3 2}$} \\
\hline Not required Value of oxytocin to avoid blood transfusion \\
\hline \multicolumn{2}{|c|}{ Items } & Value & $\mathbf{9 5 \%}$ CI \\
\hline \multicolumn{2}{|c|}{ Rate reduction of transfusion } & $13.4 \%$ & $0.0 \%-23.5 \%$ \\
\hline Efficacy in avoiding transfusion & $14.8 \%$ & $0.0 \%-24.4 \%$ \\
\hline Relative Rate of transfusion & 0.8 & $0.7-0.9$ \\
\hline Number needed to prevent transfusion & 7.4 & $4.3-10.0$ \\
\hline
\end{tabular}

${ }^{\wedge}$ Chi square test. . CI: Confidence interval 
The median amount of blood transfusion in oxytocin group was 500 with the range $500-1500 \mathrm{ml}$ while in control group was 1000 with the range

500-1500 showing that Blood transfusion amount was significantly fewer among oxytocin group (Table 5).

Table (4): Blood transfusion amount ( $\mathrm{mL}$ ) among the studied groups

\begin{tabular}{|c|c|c|c|}
\hline Groups & $\begin{array}{c}\text { Control } \\
(\mathbf{N}=\mathbf{1 5})\end{array}$ & $\begin{array}{c}\text { Oxytocin } \\
(\mathbf{N}=\mathbf{6})\end{array}$ & \multirow{2}{*}{$\mathbf{P}$} \\
\hline Median (IQR) & $1000.0(1000.0-1500.0)$ & $500.0(500.0-1125.0)$ & \multirow{2}{*}{$<\mathbf{0 . 0 0 1}$} \\
\hline Range & $500.0-1500.0$ & $500.0-1500.0$ & \\
\hline
\end{tabular}

IQR: Inter-quartile range. ${ }^{\wedge}$ Mann Whitney test

\section{DISCUSSION}

There were no significant differences between the studied groups regarding age, BMI, parity, myoma number, size and uterine size.

Intra-operative blood loss was significantly fewer among oxytocin group; the mean blood loss decrease due to oxytocin was $155.0 \pm 12.6$. These results were in agreement with the results of Atashkhoei et al. (2017) who showed that the mean intraoperative blood loss in oxytocin group was less than in control group. Also, thee showed that Intraoperative blood loss was significantly fewer among oxytocin group.

On the other side, Çetin et al. (2019) reported that preoperative blood loss did not differ between the oxytocin group and the placebo group. This could be due to timing of administration of oxytocin. We started intravenous oxytocin infusion immediately after anesthesia was initiated and continued its use throughout the operative procedure. So, there was at least 20 minutes before oxytocin reached its maximal effect on a non-pregnant uterus. To the contrary, oxytocin was administered when the uterine incision was begun in the study by Çetin et al. (2019), and the onset of action is within 1 minute via the intravenous route in the pregnant state, and the duration lasts for 1 hour. As a result, it is reasonable to suggest that oxytocin takes more time to achieve its onset in the non-pregnant uterus. Therefore, if the infusion was started after the uterine incision was made, the uterus may have responded partially or not at all to the medication.

There was no significant difference between the studied groups regarding preoperative hemoglobin. Postoperative hemoglobin was significantly higher among oxytocin group; hemoglobin reduction was significantly lower among oxytocin group. The mean $\mathrm{Hb}$ reduction decrease due to oxytocin.

These results are in agreement with the results of Atashkhoei et al. (2017) who showed that the mean preoperative $\mathrm{Hb} \%$ was insignificant between the studied groups. $\mathrm{Hb} \%$ reduction was significantly lower among oxytocin group.

On the contrary, Çetin et al. (2019) reported that the two groups did not differ significantly in the change in hemoglobin level from the day before the operation and $48 \mathrm{~h}$ after surgery.

There was no significant difference between the studied groups regarding preoperative hematocrit. Postoperative 
hematocrit was significantly higher among oxytocin group and hematocrit reduction was significantly lower among oxytocin group.

These results were in agreement with the results of Atashkhoei et al. (2017) who showed that there was no significant difference between the studied groups regarding preoperative hematocrit. Postoperative hematocrit was higher among oxytocin group.

Blood transfusion was significantly less frequent among oxytocin group. And these results were in agreement with the results of Atashkhoei et al. (2017) who reported that blood transfusion was significantly less frequent among oxytocin group. Also, Atashkhoei et al. (2017) reported that blood transfusion was significantly less frequent among oxytocin group.

On the contrary, Çetin et al. (2019) reported that rates of auto-transfusion were similar in both groups.

\section{CONCLUSION}

The infusion of oxytocin intraoperatively (immediately after induction of general anesthesia) may be safe and reliable method to help decrease blood loss during abdominal myomectomy.

\section{REFERENCES}

1. Atashkhoei S, Fakhari S, Pourfathi H, Bilehjani E, Garabaghi PM and Asiaei A (2017): Effect of oxytocin infusion on reducing the blood loss during abdominal myomectomy: a double- blind randomised controlled trial. BJOG: An International Journal of Obstetrics \& Gynaecology, 124(2):292-8.

2. Atashkhoei S, Fakhari S, Pourfathi H, Bilehjani E, Garabaghi PM and Asiaei A (2017): Effect of oxytocin infusion on reducing the blood loss during abdominal myomectomy: a double- blind randomised controlled trial. BJOG: An International Journal of Obstetrics \& Gynaecology, 124(2):292-8.

3. Çetin BA, Mathyk BA, Köroğlu N, Soydar A, Demirayak $G$ and Çift $T$ (2019): Oxytocin infusion reduces bleeding during abdominal myomectomies: a randomized controlled trial. Archives of Gynecology and Obstetrics, 299(1):151-7.

4. Helal AS, Abdel-Hady EL-S, Refaie E, El Shamy M, El Fattah RA and Mashaly AE (2010): Preliminary uterine artery ligation versus pericervical mechanical tourniquet in reducing haemorrhage during abdominal myomectomy. Int $\mathrm{J}$ Gynaecol Obstet., 108:233-5.

5. Ikhena DE and Bulun SE (2018): Literature review on the role of uterine fibroids in endometrial function. Reproductive Sciences, 25(5):635-43.

6. Kongnyuy EJ and Wiysonge CS (2011): Interventions to reduce haemorrhage during myomectomy for fibroids. Cochrane Database Syst Rev., 5: Cd005355.

7. Mısırlığlu S, Türkgeldi E, Yağmur H, Urman B and Ata B (2018): Use of a gelatinthrombin hemostatic matrix in obstetrics and gynecologicl surgery. Turkish Journal of Obstetrics and Gynecology, 15(3):193-48.

8. Mohamed SE, Mansour DY and Shaker AN (2019): The effect of misoprostol on intraoperative blood loss during myomectomy operation: Randomized controlled trial. Evidence Based Women's Health Journal, 9(1):363-71.

9. Schüring AN, Garcia-Rocha GJ and Schlösser HW (2011): "Perioperative complications in conventional and microsurgical abdominal myomectomy": Arch Gynecol Obstet., 284: 137- 54.

10. Shokeir T, El-lakkany N, Sadek E, Elshamy $M$ and Abu Hashim $H$ (2011): An RCT: use of oxytocin drip during hysteroscopic endometrial resection and its effect on operative blood loss and glycine 
deficit. J Minim Invasive Gynecol., 18:48993.

11. Tektook NK, Kadhim $E$ and Saeed A (2019): Effect of oxytocin on changing hemodynamic parameters (heart rate and blood pressure) in cesarean section patients. Journal of Medical \& Allied Sciences, 9(2):264-71.
12. Thomas RL, Winkler N, Carr BR, Doody KM and Doody KJ (2010): Abdominal myomectomy - a safe procedure in an ambulatory setting. Fertil Steril., 94:2277-80.

13. van der Does $L$, Kazi N, Baxi R, Haworth $L$ and Washington $K$ (2018): Myomectomy. Obstetrics \& Gynecology, 131:18-23. 
تأثير إستخدام الأوكسيتوسين في الحد من النزبف أثناء

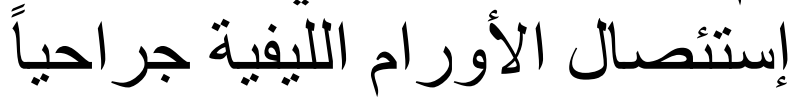

عبد العظيم محمد أحمد، أحمد أسامة عبد المتعال، أسامة محمود عبد الرحيم قسم التوليد وأمراض النساء، كلية الطب، جامعة الأزهر

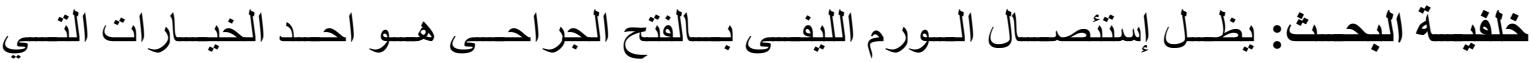

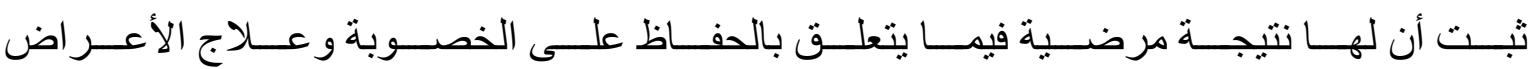

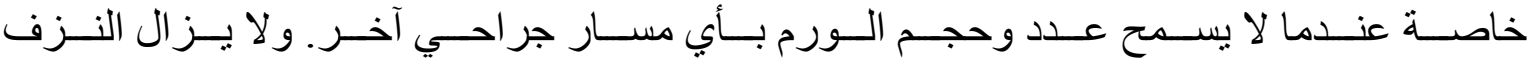

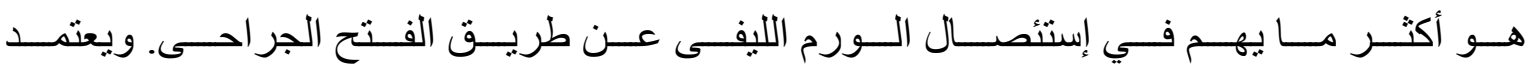

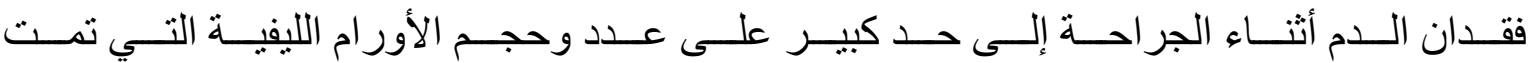

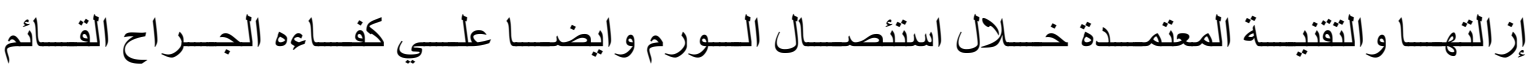
بالعمليه. - (بالي.

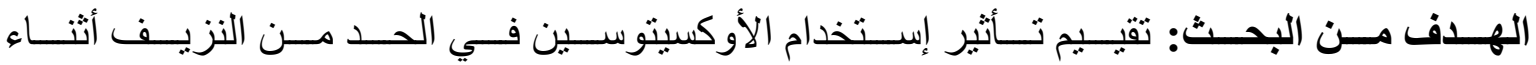
إستئصسال الأورام الليفية.

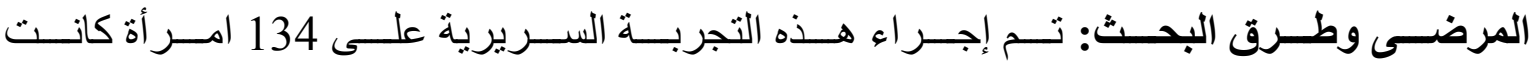

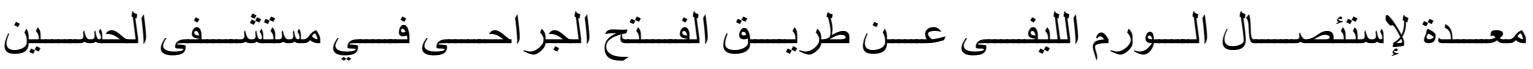

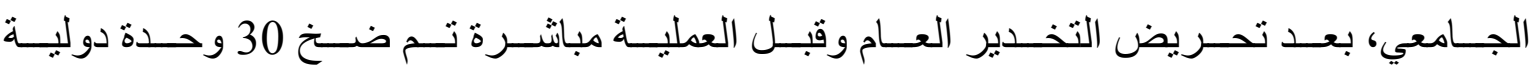

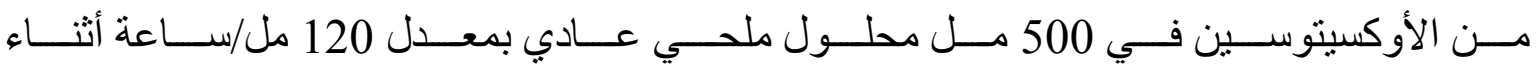

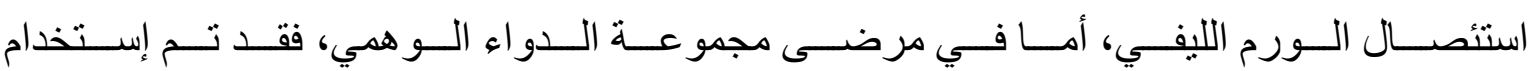
محلول ملحي طبيعي بنفس الحجم و المعدل.

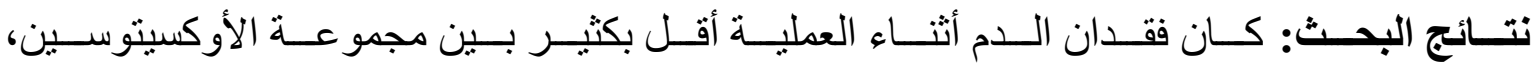

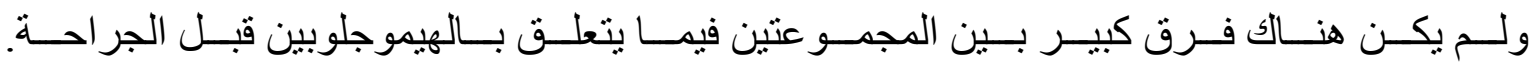
وكان الهيموجلوبين بعد العملية الجر احية أعلى بكثير بين مجموعة الأوكسيتوسين.

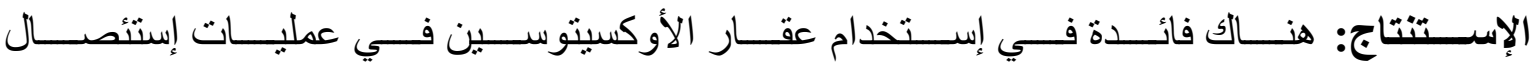
الأورام الليفيه. 